\title{
Erstatningsvern ved personskade på saksområder hvor kvinner er typiske skadelidte
}

Førsteamanuensis ph.d. Birgitte Hagland

Institutt for privatrett, Juridisk fakultet, Universitetet i Oslo*

Artikkelen er trykket i Tidsskrift for erstatningsrett, forsikringsrett og trygderett, 2018 nr 2-3, s.79- 107.

Birgitte Hagland er førsteamanuensis ved Institutt for privatrett, UiO. Hagland arbeider primært med erstatningsrett og juridisk metode, og har skrevet artikler og bøker innenfor flere fagområder.

E-post: birgitte.hagland@jus.uio.no

\section{Sammendrag:}

Artikkelen undersøker om Høyesteretts tilnærming til erstatningsvern ved personskade i tilstrekkelig grad ivaretar kvinners erstatningsrettslige stilling på saksområder hvor kvinner er typiske skadelidte. Utgangspunktet for analysen er senere års rettspraksis, hvor spørsmålet om erstatningsvern avgjøres etter en bredt anlagt interesseavveining. Et fellestrekk ved dommene er at det er vanskelig å komme utenom et kjønnsperspektiv; de omhandler saksområder hvor kvinner er typiske skadelidte. Spørsmålet om det er rom for et kvinneperspektiv i erstatningsrettslige ansvarsvurderinger, og hvilken rettslige forankring det skal ha, synes hittil utprøvd i norsk erstatningsrett. Artikkelen løfter videre frem FNs kvinnediskrimineringskonvensjon (KDK) - en konvensjon som fremstår som et tilnærmet ukjent rettsgrunnlag i norsk rett, til tross for sin særlige rettskildemessige status - og undersøke konvensjonens gjennomslagskraft.

Nøkkelord: Erstatningsvern, kvinners erstatningsrettslige stilling, diskriminering, prostitusjonsinntekter, uønsket barn, Kvinnediskrimineringskonvensjonen (KDK), folkerett 


\section{Innledning}

Et grunnvilkår for erstatning er at skaden har rammet en erstatningsvernet interesse. Generelt gjelder en alminnelig plikt til ikke å skade andres person, og det er sikker rett at den personlige integritet i sin alminnelighet er erstatningsvernet. Høyesterett har likevel en sjelden gang fått seg forelagt spørsmål om erstatningsvern på personskaderettens område. Vi har et fåtall dommer: Nyest i rekken er HR-2017-2352-A (prostitusjonsinntekter) om erstatningsvern for tapte prostitusjonsinntekter. Dommen kan ses i sammenheng med en enstemmig dom som kom året før, som handler om restitusjon og erstatning for opptjente inntekter som bakmenn har fratatt prostituerte, jf. HR-2016-2491-A (restitusjon). ${ }^{1}$ Rettstilstanden etter dommene er at «prostituertes forbigående tap av fremtidsinntekter» ikke er erstatningsvernet, mens tap av opptjente inntekter har erstatningsvern. I tillegg har vi Rt. 1999 s. 203 (sterilisering) og Rt. 2013 s. 1689 (fostervannsprøve), som begge handler om erstatningsvern for tap med nær tilknytning til at et barn er født - til tross for at helsehjelp skulle forhindret fullgått graviditet og fødsel. Høyesterett har i begge de sistnevnte dommene lagt til grunn at tap med nær tilknytning til fødselen av et uønsket barn ikke er erstatningsvernet.

Et fellestrekk ved dommene er at spørsmålet om erstatningsvern avgjøres etter en bredt anlagt interesseavveining. I den nyeste dommen, HR-2017-2352-A (prostitusjonsinntekter), tar flertallet utgangspunkt i Rt. 1999 s. 203 (sterilisering) og Rt. 2013 s. 1689 (fostervannsprøve) og formulerer følgende vurderingstema: om den skadelidte interessen «fortjener rettsordenens beskyttelse» (avsnitt 36). ${ }^{2}$ Videre legges det til grunn at spørsmålet om erstatningsvern skal avgjøres etter en «bred helhetsvurdering», beroende på «en konkret bedømmelse av hensynet til

\footnotetext{
* Jeg takker redaksjonen og fagfeller for konstruktive og inspirerende innspill til artikkelarbeidet. En særlig takk går også til professor Kåre Lilleholt, professor Ole-Andreas Rognstad og postdoktor Tone L. Wærstad, for gode faglige diskusjoner.

${ }^{1}$ HR-2017-2352-A (prostitusjonsinntekter) avsnitt 62. Dommen er avsagt under dissens (3-2). Både flertallet og mindretallets dissens kommer vi tilbake til. Fra tidligere hadde vi en noe sprikende lagmannsrettspraksis: Det foreligger tre dommer hvor det legges til grunn at slike inntekter er vernet, mens vi har én dom hvor prostitusjonsinntekter ikke anses vernet, jf. hhv. RG 2007 side 1083, LB-2005-138054, RG 2008 side 1137 og LG2009-23028.

${ }^{2}$ Med videre henvisning til Viggo Hagstrøm og Are Stenvik, Erstatningsrett (Oslo 2015) (heretter Hagstrøm/Stenvik).
} 
de skadelidtes og samfunnets interesser vurdert generelt» (avsnitt 36 og 37). ${ }^{3}$ Utover dette gir rettspraksis i mindre grad veiledning med hensyn til hvordan dette bredt anlagte vurderingstemaet skal operasjonaliseres. Hvilke øvrige rettskilder og vurderingsmomenter som kan inngå i fastsettelsen av om en skadelidt interesse har erstatningsvern, fremstår i mindre grad som avklart. Til dette kommer at både HR-2017-2352-A (prostitusjonsinntekter) og Rt. $2013 \mathrm{~s}$. 1689 (fostervannsprøve) er skarpe dissensdommer (3-2) hvor mindretallet legger til grunn et annet vurderingstema og til dels andre rettslige utgangspunkter enn flertallet. ${ }^{4}$ Betydningen kommer jeg til tilbake til i artikkelens analyser.

Et annet fellestrekk ved dommene er at det er vanskelig å komme utenom et kjønnsperspektiv; de omhandler saksområder hvor kvinner er typiske skadelidte: Manglende helsehjelp i forbindelse med familieplanlegging har særlig betydning for kvinner, som må gjennomgå svangerskap og fødsler. Sikker kunnskap om kjønnsfordeling i sexkjøpsmarkedene har vi ikke. Men sentral rapportering og forskning om sexkjøpsmarkedene og samfunnets samlede ressursbruk når det kommer til prostitusjon (typisk hjelpetiltak og politiinnsats), bygger på en alminnelig oppfatning om at det er flere kvinner enn menn som arbeider som prostituerte, og som er ofre for menneskehandel. ${ }^{5}$

Formålet med denne artikkelen er todelt: For det første å undersøke om Høyesteretts tilnærming til erstatningsvern ved personskade i tilstrekkelig grad ivaretar kvinners erstatningsrettslige stilling på saksområder hvor kvinner er typiske skadelidte, jf. punkt 3. For det andre å løfte frem FNs kvinnediskrimineringskonvensjon $(\mathrm{KDK})^{6}$ - en konvensjon som fremstår som et tilnærmet ukjent rettsgrunnlag i norsk rett, til tross for sin særlige rettskildemessige status - og undersøke konvensjonens gjennomslagskraft når det gjelder fastsettelsen av erstatningsvern på saksområdene hvor kvinner er typiske skadelidte, jf. punkt 4.

\footnotetext{
${ }^{3}$ jf. HR-2017-2352-A (prostitusjonsinntekter) avsnitt 38, Rt. 1999 s. 203 (sterilisering) på side 206-207, Rt. 2013 s. 1689 (fostervannsprøve) avsnitt 40.

${ }^{4}$ HR-2017-2352-A (prostitusjonsinntekter) og Rt. 2013 s. 1689 (fostervannsprøve)

${ }^{5}$ Se eksempelvis Likestillings- og diskrimineringsombudets rapport til CEDAW i 2017, CEDAW 2017 Ombudets rapport til FNs kvinnekomité - et supplement til Norges niende periodiske rapport, http://www.ldo.no/globalassets/brosjyrer-handboker-rapporter/rapporter_analyser/rapporter_diverse/cedaw2017.pdf (sist besøkt 1. august 2018) punkt 5.1, og Rapport 0214/30 Vistas Analyse om «Evaluering av forbudet mot kjøp av seksuelle tjenester», utført på oppdrag fra Justis- og beredskapsdepartementet i 2014 (heretter Vista Rapport).

${ }^{6}$ De forente nasjoners internasjonale konvensjon 18. desember 1979 om avskaffelse av alle former for diskriminering av kvinner (KDK).
} 


\section{Nærmere om rettsgrunnlaget for vern mot diskriminering}

Om en anlegger et kvinneperspektiv på rettsutviklingen, kan det være grunn til å stille spørsmål om utviklingen i tilstrekkelig grad ivaretar kvinners erstatningsrettslige stilling. Dersom utformingen av erstatningsvern ved personskade resulterer i at kvinner reelt sett får en svakere erstatningsrettslig stilling enn menn, fordi saksområder hvor kvinner er typiske skadelidte, ikke er erstatningsvernet og tapene deres ikke erstattes, kan det være i strid med det grunnlovfestede diskrimineringsvernet som følger av Grl. § 98.

Bestemmelsen i Grl. $§ 98$ fastsetter at «intet menneske må utsettes for usaklig eller uforholdsmessig forskjellsbehandling». Diskrimineringsvernet i Grunnloven er ikke knyttet til bestemte diskrimineringsgrunnlag, ${ }^{7}$ og omfatter både direkte og indirekte diskriminering. Direkte diskriminering foreligger når en person behandles dårligere enn andre i samme situasjon, uten at forskjellsbehandlingen har saklig grunn. Indirekte diskriminering foreligger når en regel eller en praksis som tilsynelatende er nøytral, reelt sett innebærer forskjellsbehandling. ${ }^{8}$

Grunnlovfestingen av ikke-diskrimineringsprinsippet skal fungere som skranke for lovgiver og domstoler. ${ }^{9}$ Samtidig må diskrimineringsforbudets nærmere innhold fastlegges med utgangspunkt i de øvrige rettsgrunnlagene som skal motvirke diskriminering. ${ }^{10}$ Forbudet mot diskriminering følger både av Norges folkerettslige forpliktelser, EØS-retten og en rekke nasjonale lover. ${ }^{11}$ Sentralt i vår sammenheng er at diskrimineringsforbudet stiller krav til erstatningsrettens regelinnhold og regelanvendelse. ${ }^{12}$ Erstatningsregler som tilsynelatende er utformet nøytralt, vil kunne omfattes av forbudet mot indirekte diskriminering dersom regelinnholdet eller regelanvendelsen reelt sett medfører at kvinner får en svakere erstatningsrettslig stilling enn menn.

\footnotetext{
${ }^{7}$ Det vil si forskjellsbehandling som har sammenheng med kjennetegn ved en person, som eksempelvis kjønn, graviditet, rase eller religion.

${ }^{8}$ Se Dok. Nr. 16 (2011-2012) Rapport fra Menneskerettighetsutvalget om menneskerettigheter i Grunnloven, punkt 26.4.2.1.

${ }^{9}$ Op.cit., punkt 26.6.2.3.

${ }^{10}$ Se bl.a. Vibeke Blaker Strand, «Håndheving av diskrimineringsvernet i møte med andre lover i Velferdsstaten», i Rettigheter $i$ velferdsstaten - begreper, trender, teorier, Gyldendal Juridisk 2016 (heretter Blaker Strand) punkt 2.

${ }^{11}$ I et kvinneperspektiv kan særlig nevnes lov om likestilling og forbud mot diskriminering av 16. juni 2017 nr. 51 , EMK artikkel 14 og Kvinnediskrimineringskonvensjonen (KDK).

${ }^{12}$ Se bl.a. Blaker Strand s. 136.
} 
I erstatningsrettslig sammenheng tenker en nok først og fremst på erstatningsansvar som rettsvirkning ved overtredelse av lovbestemte diskrimineringsforbud, og dermed som et instrument for å sørge for å sikre et effektivt diskrimineringsvern, jf. bl.a. likestillings- og diskrimineringsloven $\S 38$. Diskrimineringsforbudets funksjon som tolkningsfaktor i tradisjonelle erstatningsrettslige ansvarsvurderinger er hittil viet lite oppmerksomhet. Spørsmålet om det her er rom for et kvinneperspektiv, og hvilken rettslig forankring det skal ha, synes hittil uprøvd i norsk erstatningsrett. Tar en utgangspunkt i diskrimineringsforbudets funksjon som tolkningsfaktor i fastleggelsen av erstatningsvern på saksområder hvor kvinner er typiske skadelidte, må det undersøkes hvilke rettsgrunnlag som eventuelt kan bidra til ivaretakelsen av kvinners erstatningsrettslige stilling. Hvilke(t) rettsgrunnlag det kan være tale om å anvende, beror både på hva slags skadesituasjon og hvilke(t) skadetilfelle det er tale om. ${ }^{13}$

I denne artikkelen er det særlig ett rettsgrunnlag som skal undersøkes nærmere, nemlig FNs kvinnediskrimineringskonvensjon (KDK). KDK er - i motsetning til Den europeiske menneskerettighetskonvensjon (EMK) - et rettsgrunnlag som hittil har hatt liten gjennomslagskraft i høyesterettspraksis, til tross for at også denne konvensjonen har tilsvarende rettskildemessige status som EMK: ${ }^{14}$ Også KDK er gjennom menneskerettsloven (mrl.) gjort til norsk lov med forrang foran alminnelig lovgivning, jf. mrl. $\S 2 \mathrm{nr} .5 \mathrm{og} \S 3$. Konvensjonens rettskildemessige status gjør at den skiller seg fra andre alminnelige rettsgrunnlag som typisk inngår i en erstatningsvurdering, ganske enkelt ved å ha en annen rettskildemessig betydning. Samtidig følger det av Grl. § 92 at «[s]tatens myndigheter skal respektere og sikre menneskerettighetene slik de er nedfelt i denne grunnlov og $\mathrm{i}$ for Norge bindende traktater om menneskerettigheter». Det vil si at norske domstoler har en selvstendig plikt til å sørge for at den alminnelige erstatningsretts regelinnhold og regelanvendelse ikke kommer i strid med KDK. I plenumsdommen HR-2016-2554-P (Holship) uttaler førstvoterende (med tilslutning fra samtlige seksten dommere) at Grl. § 92 ikke kan forstås som en inkorporasjonsbestemmelse, men «må forstås som et pålegg til domstolene og andre myndigheter om å håndheve menneskerettighetene på det nivået de er gjennomført i norsk rett» (avsnitt 70).

\footnotetext{
${ }^{13}$ For en grunnleggende fremstilling av diskrimineringsansvaret kan det vises til Sabina Hellborg, Diskrimineringsansvar - en civilrättslig undersökning av förutsättningarna för ansvar och ersättning vid diskriminering, Uppsala 2018.

${ }^{14}$ Kort om betydningen av EMK på områder som gjelder kvinners erstatningsrettslige stilling, se punkt 4.1.
} 


\section{Om Høyesteretts tilnærming til erstatningsvern ved personskade og kvinners erstatningsrettslige stilling på saksområder hvor kvinner er typiske skadelidte}

\subsection{Innledning}

I dette avsnittet behandles spørsmålet om Høyesteretts tilnærming til erstatningsvern ved personskade i tilstrekkelig grad ivaretar kvinners erstatningsrettslige stilling på saksområder hvor kvinner er typiske skadelidte. Utgangspunktet for analysen er de sentrale bidragene til rettsutviklingen av erstatningsvern for personskade som forannevnte dommer representerer. Dommene om erstatningsvern for prostitusjonsinntekter, HR-2017-2352-A (prostitusjonsinntekter) og HR-2016-2491-A (restitusjon), analyseres i punkt 3.2, mens dommene knyttet til erstatningsvern for tap som oppstår i tilknytning til fødsel av uønskede barn, Rt. 1999 s. 203 (sterilisering) og Rt. 2013 s. 1689 (fostervannsprøve), er gjenstand for analyse i punkt 3.3.

\subsection{Erstatningsvern for prostitusjonsinntekter}

\subsubsection{Introduksjon}

Som nevnt innledningsvis, har vi to forholdsvis nye dommer om erstatning for tapte prostitusjonsinntekter, HR-2017-2352-A (prostitusjonsinntekter) og HR-2016-2491-A (restitusjon). Førstnevnte dom hadde sin bakgrunn i ran og mishandling av prostituerte kvinner. Under ranene ble det utøvet fysisk og psykisk vold (drapstrusler). Kvinnene ble påført skader slik at de ikke kunne arbeide med salg av seksuelle tjenester i to uker. Saken for Høyesterett gjaldt kun kvinnenes krav om erstatning for lidt inntektstap, satt til 50000 kroner. ${ }^{15}$ Spørsmålet var om de tapte prostitusjonsinntektene hadde erstatningsvern. Et flertall på tre dommere kom til at «prostituertes forbigående tap av fremtidsinntekter» ikke er erstatningsvernet (avsnitt 62). Mindretallet la til grunn at «tapte prostitusjonsinntekter» ikke er unntatt fra erstatningsvern (avsnitt 79). ${ }^{16}$ De skadelidte kvinnene ble derfor ikke tilkjent erstatning for sine inntektstap fra respektive skadevoldere.

\footnotetext{
${ }^{15}$ Oppreisningserstatning og erstatning for fraranede kontanter og gjenstander var allerede tilkjent.

${ }^{16}$ Fra tidligere hadde vi en noe sprikende lagmannsrettspraksis: Det foreligger tre dommer hvor det legges til grunn at slike inntekter er vernet, mens vi har én dom hvor prostitusjonsinntekter ikke anses som vernet, jf. hhv. RG 2007 side 1083, LB-2005-138054, RG 2008 side 1137 og LG-2009-23028.
} 
Dommen fra 2016, HR-2016-2491-A (restitusjon), gjelder også erstatning for prostitusjonsinntekter, men da allerede opparbeidede prostitusjonsinntekter som bakmenn hadde fratatt den prostituerte. Dommen er lite påaktet i erstatningsrettslig sammenheng, antakelig fordi hoveddelen av denne dommen gjaldt restitusjon av opptjente prostitusjonsinntekter - det vil si rede penger - etter obligasjonsrettslige prinsipper. Én av de tiltalte i saken ble imidlertid holdt erstatningsansvarlig etter alminnelige deliktsregler for å ha medvirket til skadelidtes tap, fordi han var «del av handlingsfellesskapet som forårsaket at de fornærmede ble fratatt sine inntekter» (avsnitt 96). ${ }^{17}$ Førstvoterende konstaterer kort at erstatningskravet «på betaling av inntektene må anses som en erstatningsrettslig vernet interesse», og viser til begrunnelsen gitt hva gjelder restitusjon. Dommen er enstemmig.

Dersom en sammenholder dommene, tegner det seg et broket bilde med hensyn til hvordan erstatningsvernet utmeisles, og i hvilken grad rettsutviklingen åpner for å ivareta et kvinneperspektiv. Ser en nærmere på valgte rettslige utgangspunkter, konkretisering av vurderingstema, argumentasjonslinjer, konkrete vurderinger og verdistandpunkt, kommer forskjellene tydelig frem. Vi skal se nærmere på hvordan.

\subsubsection{Observasjon $1-$ ulike rettslige utgangpunkter}

Den første observasjonen vi kan gjøre, er at selv om 2017-dommen (prostitusjonsinntekter) synes å bygge på et omforent syn hva gjelder erstatningsvern som grunnvilkår for erstatning, fastsatt etter en helhetlig drøftelse, synes fraksjonene delt med hensyn til hvilke rettslige utgangspunkter som skal legges til grunn for vurderingen. Flertallet innleder sitt votum med å vise til hvordan tidligere rettspraksis har oppstilt som grunnvilkår for erstatning at den skadelidte interessen har erstatningsvern, og at spørsmålet om erstatningsvern må avgjøres uavhengig av loven. Førstvoterende understreker at det ikke er tale om å gjøre unntak fra vern. Den «overordnede problemstillingen» formuleres deretter som et spørsmål om «en interesse som fortjener rettsordenens beskyttelse», hvor vernet for prostitusjonsinntekter må «bero på en konkret bedømmelse av hensynet til de skadelidte og samfunnets interesser vurdert generelt».

\footnotetext{
${ }^{17}$ Domshenvisningen til napster.no-saken, Rt. 2005 s. 41, gir liten veiledning. I rettslitteraturen er dommen tatt til inntekt for eksistensen av et medvirkningsansvar, jf. særlig Birgitte Hagland, Erstatningsbetingende medvirkning (Oslo 2012) (heretter Hagland), kapittel 4.
} 
Mindretallet presiserer innledningsvis at det har et annet syn enn flertallet både med hensyn til det rettslige utgangspunktet og den konkrete vurderingen av om tapte prostitusjonsinntekter har erstatningsvern (avsnitt 65). I votumet tas det utgangspunkt i at skadelidte er påført en personskade, og at skadelidte da har krav på å få dekket sine økonomiske tap av skadevolderne. Dette hjemler mindretallet direkte i skl. § 3-1 som bestemmer at erstatning for skade på person blant annet skal dekke «lidt skade» og «tap i fremtidig erverv» (avsnitt 66). Mindretallet presiserer deretter: «For meg er derfor utgangspunktet dette: Det følger av loven at den personskadelidtes individuelle ervervstap har erstatningsrettslig vern» (avsnitt 66). Dersom inntektstapet ikke skal anses vernet, fremholder mindretallet at «det må oppstilles et unntak fra $\S$ 3-1» (avsnitt 67). Det kan umiddelbart synes noe underlig at en utmålingsregel brukes direkte som hjemmel for å fastsette et erstatningsvern. I rettslitteraturen er det imidlertid ikke uvanlig å utlede av § 3-1 at den personlige integriteten er vernet, og at skadelidte har krav på full kompensasjon for sitt økonomiske tap. ${ }^{18}$

Selv om både flertallet og mindretallet foretar en helhetlig drøftelse av vilkåret om erstatningsvern, synes ulikt syn på de rettslige utgangspunktene for vurderingen å prege flertallets og mindretallets videre begrunnelse, i den forstand at valg av rettslig utgangspunkt gir åpning for ulike argumentasjonslinjer: Etter min mening åpner flertallets rettslige utgangspunkt, med en avveining av skadelidtes interesse og samfunnets interesser generelt vurdert, i større grad for en instrumentell tilskjæring av erstatningsvernet enn det en mer tradisjonell begrunnelse for erstatning ved personskade - reparasjon og prevensjon av personskade - åpner for. En instrumentell tilnærming til erstatningsretten innebærer kort forklart at erstatningsreglene brukes som et instrument for å sikre de interessene en ønsker å prioritere eller sikre effektivt gjennomslag. Slike effektivitetsbetraktninger er best kjent fra EU-retten, hvor (trusselen om) erstatningsansvar brukes som instrument for å sikre effektivt gjennomslag for normregulering og de interesser normeringen skal ivareta. I norsk erstatningsrett er diskusjonen om det er rom for effektivitetsbetraktninger, primært knyttet til fastleggelsen av erstatningsansvar for rene

\footnotetext{
${ }^{18}$ Se blant annet Hagstrøm/Stenvik kapittel 3.2.1 og Trine Lise Wilhelmsen og Birgitte Hagland, Om erstatningsrett - med utgangspunkter i tekster av Peter Lødrup (Oslo 2017) (heretter Wilhelmsen/Hagland), kapittel 23. En detalj det kan være interessant å merke seg, er at mindretallet bruker samme metodiske tilnærming til spørsmålet om tolkningen av skl. § 3-1 som ved fastleggingen av at vi her står overfor en skattbar inntekt, jf. skatteloven $\S 5-1$ (unntak kan ikke innfortolkes for prostitusjonsinntekter).
} 
formuestap (og særlig såkalte direktekrav), ${ }^{19}$ mens det for personskader synes å være alminnelig enighet om at erstatningsrettens grunnleggende funksjon er reparasjon og prevensjon av skade. I et kvinneperspektiv er observasjonen interessant, fordi en instrumentell tilnærming til erstatningsretten på personskaderettens område åpner for å prioritere et kvinneperspektiv i de skadetilfellene hvor kvinner er typiske skadelidte, også der etiske og/eller samfunnsmessige motforestillinger (som her) gjør seg gjeldende. Selv om flertallet - som vi skal se - prioriterer annerledes.

Mindretallet tar utgangspunkt i § 3-1, og fremhever tydelig hva de mener det her dreier seg om å gjøre unntak fra det grunnleggende utgangspunktet for personskader: full reparasjon. Observasjonen kan tas til inntekt for at det er personskaden og erstatningsvernet av den personlige integritet som blir tyngdepunktet i vurderingen. I et kvinneperspektiv er det interessant fordi tyngdepunktet i mindre grad åpner for å prioritere andre samfunnshensyn, og fordi tilnærmingen i mindre grad synes å åpne for at erstatningsvernet perforeres - også på saksområder hvor kvinner fremstår som typiske skadelidte.

\subsubsection{Observasjon 2 - ulikt vurderingstema}

Den andre observasjonen vi kan gjøre, er at det nærmere vurderingstemaet - erstatningsvern for prostitusjonsinntekter - tilskjæres ulikt med hensyn til hva slags tap som vurderes, og da med utgangspunkt i ulikt syn på selve inntektstypen som vurderes.

I dommen fra 2016, HR-2016-2491-A (restitusjon), understreker førstvoterende at det som behandles i dommen, er tap av opparbeidet inntekt, og at han ikke tar stilling til erstatningsvern for fremtidige inntekter ved prostitusjon (avsnitt 86). I dommen fra 2017, HR-2017-2352-A (prostitusjonsinntekter), deler flertallet og mindretallet seg i synet på hva slags inntektstype det her er tale om: Flertallet taler om «kortvarige tap i fremtidige prostitusjonsinntekter», og unntar langvarig tap av ervervsevne (avsnitt 38). Mindretallet taler om tapte prostitusjonsinntekter (avsnitt 65).

\footnotetext{
${ }^{19}$ Se særlig Erling Hjelmeng, «Folkerettslig påvirkning av norsk erstatningsrett - to høyesterettsdommer», i Tidsskrift for erstatningsrett, forsikringsrett og velferdsrett side 211-229 (heretter Hjelmeng, Folkerettslig påvirkning).
} 
Terminologien i de to dommene er uklar. I dommen fra 2016, HR-2016-2491-A (restitusjon), er det strengt tatt ikke tale om noe inntektstap, men kontanter som kvinnene måtte gi fra seg. Det spesielle med kontantene var deres opphav - penger tjent ved sexsalg - men det er like fullt rede penger. Det kan derfor synes noe underlig at førstvoterende har behov for å presisere at han ikke tar stilling til fremtidig inntektstap. Samtidig bryter terminologien i dommen fra 2017, HR-20172352-A (prostitusjonsinntekter), med hvordan vi ellers i erstatningsretten tenker om lidt og fremtidig tap. Hva som skal regnes som lidt tap og fremtidig tap, er ikke direkte regulert i skadeserstatningsloven, men både i forarbeider og i rettspraksis er det lagt til grunn at det er oppgjørstidspunktet eller domstidspunktet som er skjæringstidspunktet for erstatning for lidt tap og fremtidige inntektstap, jf. Innst. E 1971 s. 12 og Rt. 2006 s. 684 og Rt. 2009 s. 425. Også i rettslitteraturen synes det å være alminnelig enighet om tidspunktet. ${ }^{20}$

Det vi egentlig står overfor i 2017-dommen, er altså ikke spørsmål om det er et fremtidig inntektstap, men hvordan erstatningsvern skal fastsettes for tapt inntekt som ikke opparbeides som følge av skaden. Når tapet omtales som «kortvarige tap i fremtidige prostitusjonsinntekter, er det en tilnærming vi gjenfinner hos den ankende part (som vant saken), både for å synliggjøre hva det hypotetiske hendelsesforløpet innebærer (avsnitt 14), og for å skille denne saken fra 2016-dommen (avsnitt 18). ${ }^{21}$ Tilnærmingen åpner for argumenter knyttet til at en individuell utmåling, basert på et hypotetisk sexsalg, er i strid med Kong Christians den Femtis Norske Lov af 1687, nærmere bestemt NL-5-1-2. ${ }^{22}$ Dette er en argumentasjonslinje som flertallet forfølger, men som mindretallet velger bort - med den begrunnelse at synet er lite tidsmessig: «Fordi utviklingen de siste tiårene har gått i retning av å legge større klander på kunden, er det mulig at ubetalt vederlag for allerede utførte prostitusjonshandlinger kan inndrives i domstolene. Jeg viser her til Hauge, Ugyldighet ved formuerettslige disposisjoner ...» (avsnitt 72).

Holdningsendringen som mindretallet her peker på, synes bedre i samsvar med holdningene som kommer til uttrykk i moderne lovgivning hva gjelder krenkelser, hvor lovgiveren i større grad enn tidligere anlegger et kvinneperspektiv. ${ }^{23}$

\footnotetext{
${ }^{20}$ Se blant annet Morten Kjelland, Erstatningsrett - en lcerebok (Oslo 2016) (heretter Kjelland), kapittel 12.1, Wilhelmsen/Hagland, kapittel 23.3.

${ }^{21}$ Som inneholder en uttrykkelig reservasjon mht. fremtidig inntektstap (avsnitt 86).

${ }^{22}$ Se også Lov om den almindelige Borgerlige Straffelovs Ikrafttræden fra $1902 \S 12$ som fastsetter at «[e]thvert Krav, hvis Erhvervelse staar i Forbindelse med sædvanemæssig Fremme af Utugt, er ugyldigt». Bestemmelsen er ikke omtalt i dommen.

${ }^{23}$ Se lederartikkel om individuelt oppreisningsansvar for seksuell krenkelse.
} 
3.2.4. Observasjon 3 - ulike argumentasjonslinjer, konkrete vurderinger og verdistandpunkt Den tredje observasjonen er at dersom en sammenlikner de konkrete argumentasjons- og vurderingsmønstrene som domsgrunnene bygger på, finner en at argumentasjonen om (manglende) erstatningsvern preges av motsetningsfylte vurderinger og verdistandpunkt. Det er et gjennomgående trekk ved dommen fra 2017, HR-2017-2352-A (prostitusjonsinntekter), at argumenter som for flertallet tilsier at «prostituertes forbigående tap av fremtidsinntekter» ikke er erstatningsvernet, for mindretallet er argumenter for vern av tapte prostitusjonsinntekter. ${ }^{24}$

Flertallet tar i sin konkrete vurdering utgangspunkt i at kjøp av seksuelle tjenester er straffbart, mens salg av seksuelle tjenester er lovlig, og rammes heller ikke av det alminnelige medvirkningsforbudet i straffeloven (avsnitt 40). Førstvoterende viser deretter at en sentral lovgrunn for sexkjøpforbudet er beskyttelse av ofre for menneskehandel og bekjempelse av alvorlig organisert kriminalitet, samtidig som «[b]egrunnelsen gir et klart budskap om at prostitusjon er sterkt uønsket av kriminal- og sosialpolitiske grunner» (avsnitt 45).

Den videre argumentasjonen bygger på en grunntanke om at det $\mathrm{i}$ vurderingen av erstatningsvern - formulert som et spørsmål om «en interesse som fortjener rettsordenens beskyttelse» - skal vektlegges hvor inntektene stammer fra, nemlig atferd som sett fra samfunnets side er uønsket. Flere systembetraktninger løftes frem i argumentasjonen: For det første strafferettslige systembetraktninger knyttet til kriminalisering av virksomhet tilknyttet prostitusjonen. Hensynet til de prostituerte selv, som en svak og utsatt gruppe, løftes frem som begrunnelse for at salg av seksuelle tjenester ikke er straffbart, og som et argument «mot at tap for fremtidige inntekter fra prostitusjon skal ha et erstatningsrettslig vern» (jf. avsnitt 50, min utheving). For det andre avtalerettslige systembetraktninger: Inntektstapet forutsetter fremtidige kjøp av seksuelle tjenester, som er straffbart. Erstatningsvern løftes derfor frem som vanskelig i relasjon til NL-51-2 om oppfyllelse av avtale med ulovlig eller støtende innhold. Utfra rettssystembetraktninger anses det som «vanskelig å bygge et rettskrav på et slikt utgangspunkt» (avsnitt 51). Skatterettslige systembetraktninger, det at det her er tale om skattepliktig inntekt, endrer ikke

\footnotetext{
${ }^{24}$ Jf. hhv. avsnitt 62 og 65 .
} 
førstvoterendes syn: «Skattelovgivningen bygger på andre hensyn enn erstatningsretten. I praksis oppgis dessuten ikke prostitusjonsinntekter til beskatning» (avsnitt 53).

Deretter synes argumentasjonen å flytte seg til mer pragmatiske betraktninger om hvilke faktiske dekningsbehov skadelidte kan antas å ha, når en tar i betraktning at erstatningsoppgjør gjerne strekker ut i tid (avsnitt 53). En form for tilfeldighetsargumentasjon løftes frem, som argument for erstatningsvern: For skadevolder er det en tilfeldig fordel om han slipper ansvar. Men «[s]å lenge det dreier seg om en skadevolder fra prostitusjonsmiljøet eller annet kriminelt miljø», legger førstvoterende til grunn at dette har «liten praktisk betydning» (avsnitt 54).

Flertallets erkjennelse av at dette er et verdivalg, kommer tydelig til uttrykk: Et manglende vern kan «oppfattes som støtende og bidra til økt utrygghetsfølelse for en allerede sårbar gruppe» (avsnitt 55). Etter førstvoterendes syn kan dette avhjelpes ved samfunnets samlede innsats. I vurderingen av spenningsforholdet mellom reparasjon og samfunnets mer overordnede interesse fremholder førstvoterende at erstatningsvern for prostitusjonsinntekter vil bidra til «alminneliggjøring av sterkt uønsket virksomhet» og «motvirke de dempende effekter kriminaliseringen av slike kjøp synes å ha hatt» (avsnitt 60).

Også mindretallet tar utgangspunkt i systembetraktninger knyttet til lovgivers valg om å kriminalisere sexkjøp og virksomhet knyttet til prostitusjon, men å tillate salg av seksuelle tjenester. Men straffelovgivningen anses ikke å kunne begrunne at tapte prostitusjonsinntekter skal unntas et erstatningsvern. Samtidig fremheves at det her er tale om en lovlig, skattepliktig inntekt. Også i synet på NL- 5-1-2 legger mindretallet en annen oppfatning til grunn: Regelen anses ikke å gi noe entydig svar på hvilket rettsvern prostitusjonsavtaler i dag har, eller å kunne begrunne at tapte prostitusjonsinntekter er unntatt (avsnitt 73). Mindretallet fremhever at å tilkjenne erstatning ikke i seg selv bidrar til å fremme prostitusjon; erstatning innebærer kun at det gjøres en økonomisk beregning av et hypotetisk hendelsesforløp. Det understrekes at erstatning verken innebærer at noen prostitusjonshandling tvinges gjennom, eller forutsetter at en slik handling skal realiseres (avsnitt 73). 
Også i sin realargumentasjon synes mindretallet å ha en annen oppfatning enn flertallet, både hva gjelder om erstatningsvern vil påvirke holdningene til prostitusjon, og hvordan beskyttelsesbehovet til gruppen best ivaretas. Det pekes bl.a. på at prostituerte er en voldsutsatt gruppe, og at et manglende erstatningsvern medfører at konsekvensene av å skade prostituerte blir færre enn av å skade andre (avsnitt 77-78).

Dersom de to votaene leses i sammenheng med dommen fra året før, HR-2016-249-A (restitusjon), fremstår det ikke umiddelbart som klart hvordan flertallets valgte argumentasjonslinje passer med den argumentasjonen som legges til grunn av en enstemmig Høyesterett i 2016-dommen. I HR-2016-249-A (restitusjon) understreker førstvoterende at han ikke tar stilling til erstatningsvern for fremtidige inntekter (avsnitt 86). I sin begrunnelse for erstatningsvern hva gjelder tapte inntekter, viser han til det som er sagt om restitusjon (egentlig av rede penger), og her er førstvoterende tydelig: «Det kan ved vurderingen av dette spørsmålet ikke være avgjørende at kravet springer ut av en samfunnsskadelig og uønsket virksomhet som prostitusjon» (avsnitt 87). Og han sier videre at «det er inngrepet i den personlige frihet og integritet - og ikke prostitusjonen - som står i forgrunnen ved vurderingen av om de fornærmedes krav har rettslig vern» (avsnitt 89).

I dommen løftes det også frem at konvensjonene som ligger til grunn for straffebestemmelsene mot menneskehandel og organisert kriminalitet, har bestemmelser om restitusjon og erstatning til ofrene. ${ }^{25}$ Førstvoterende fremhever at konvensjonsbestemmelsene er for generelt utformet til at de kan sies å forutsette et erstatningsvern for «inntekter i en situasjon som foreligger i vår sak». Konvensjonsbestemmelsene anses likevel å gi «generell støtte for at ofre for menneskehandel skal ha et reelt og godt vern mot økonomisk tap som de påføres» (avsnitt 91).

Etter min mening synes førstvoterendes argumentasjonslinjer å ligge tettere på verdi- og perspektivvalgene i mindretallets begrunnelse i 2017-dommen, og det gjelder selv om en tar høyde for reservasjonen for fremtidige inntekter. ${ }^{26} \mathrm{Og}$ hvorfor er en slik observasjon interessant?

\footnotetext{
${ }^{25}$ Se FNs konvensjon 15. november 2000 mot grenseoverskridende organisert kriminalitet, artikkel 25 nr. 2 , den tilknyttede «Palermo-protokollen» artikkel nr. 6 og Europarådets konvensjon om tiltak mot menneskehandel av 16. mai 2005 artikkel 15.

${ }^{26}$ Jf. avsnitt 86.
} 
Det kan iallfall stilles spørsmål ved om verdi- og perspektivvalget som ligger til grunn for flertallsstandpunktet i 2017-dommen - med dissens 3-2 i avdeling - representerer flertallet i en samlet Høyesterett. Og videre om Høyesterett ville komme til samme resultat om tilnærmingen til erstatningsvern ved personskade i større grad inkluderte et kvinneperspektiv, hvor ikke bare tapenes tilknytning til prostitusjon stod sentralt, men hvor betydningen av at vi her står overfor et saksområde hvor kvinner er typiske skadelidte, tydelig ble løftet frem. ${ }^{27}$

\subsubsection{Observasjon 4 - en instrumentell tilnærming til erstatningsvernet?}

Den fjerde observasjonen vi kan gjøre, er at også konklusjonene i HR-2017-2352-A

(prostitusjonsinntekter) preges av at flertallet og mindretallet gjør ulike prioriteringer.

Flertallet tar utgangspunkt $\mathrm{i}$ en overordnet vurdering av «om interessen fortjener rettsordenens beskyttelse» (avsnitt 36), og konkluderer med at «prostitusjonsmarkedets karakter overskygger de negative konsekvenser et manglende vern får for den enkelte skadelidte. Risikoen for at erstatningsvern har negative sider for de prostituerte som gruppe, overskygger også at det kan virke støtende at en skadevolder ikke skal måtte gjøre opp for den prostituertes forbigående tap av fremtidsinntekter [...]. Med i totalbildet hører også at det som en prostituert blir fratatt, har alminnelig erstatningsrettslig vern» (avsnitt 62).

Konklusjonen innebærer at erstatningsrettens hovedhensyn - reparasjon og prevensjon av skade - veies mot andre hensyn, og prioriteres bort til fordel for samfunnets interesse i å motarbeide visse typer atferd. ${ }^{28}$ Vi synes å stå overfor en instrumentell tilnærming til spørsmålet om erstatningsvern, hvor erstatningsansvar brukes som et instrument for effektivt å sikre de interesser som flertallet mener skal prioriteres - de uønskede samfunnsvirkningene av prostitusjonsmarkedene og prostituerte som gruppe, jf. særlig avsnitt 60-62.

\footnotetext{
${ }^{27}$ Det skal sies at én av dommerne som stemte med flertallet i 2017-dommen, også deltok i den enstemmige dommen i 2016. Det er altså mulig at det er avgjørende forskjell på allerede opptjente prostitusjonsinntekter - rede penger - som bakmenn tar fra de prostituerte, og inntekter som prostituerte taper i en «kortvarig periode» fordi de blir utsatt for vold fra horekunder, bakmenn eller andre, og ikke kan arbeide. Det kan hevdes at tilknytning til prostitusjon er klarere i den siste dommen. Men det er vanskelig å få tak i hvorfor tap som må tilskrives et hypotetisk sexkjøp, har sterkere tilknytning til prostitusjon enn rede penger som faktisk er opptjent ved allerede gjennomførte salg av seksuelle tjenester. Begrunnelsen for at en (mulig) forskjell i tilknytning skal være avgjørende, lar seg vanskelig lese ut av de to dommene.

${ }^{28}$ Ifølge forarbeidene til skadeserstatningsloven er det å gjenopprette skaden et hovedformål i erstatningsretten, jf. NOU 1977: 33 side 23 og Ot.prp. nr. 33 (1988-89) side 16.
} 
Mindretallet legger til grunn at dersom inntektstapet skal unntas fra erstatningsvern, må det baseres på et unntak fra skl. § 3-1. Ifølge mindretallet kan et slikt unntak ikke bygges på «virkningene av at erstatning for tapte prostitusjonsinntekter tilkjennes eller ikke [...] fordi de vil være usikre, til dels svært usikre» (avsnitt 75). De prostituerte utgjør en voldsutsatt gruppe, og gruppens særlige behov for rettsvern står derfor sentralt. Det tilsier at deres inntektstap har samme erstatningsrettslige vern som andres inntektstap (avsnitt 77). Mindretallets konklusjon innebærer en prioritering av reparasjonshensynet, som tradisjonelt begrunner erstatningsansvaret ved personskade, ${ }^{29}$ samtidig som argumentasjonen tydelig er knyttet til prevensjonshensynet slik vi kjenner det for personskader: Den fysiske integriteten blir bedre vernet dersom skadevolderen må betale.

Sett hen til artikkelens overordnede tematikk, erstatningsvernet ved personskade og kvinners rett til erstatning, kan det argumenteres for at mindretallets rettslige løsning best ivaretar kvinners erstatningsrettslige stilling, rett og slett ved å sette hensynet til full reparasjon og prevensjon først. Flertallets formulering åpner for en instrumentell tilnærming til erstatningsretten, og spørsmålet er om og hvordan en slik tilnærming kan ivareta et kvinneperspektiv.

En instrumentell tilnærming til erstatningsretten innebærer at en må gjøre seg opp en mening om hvilke interesser som prioriteres. Prostitusjonsmarkedene bringer imidlertid med seg en gordisk knute av problemer, slik at spørsmålet om hvilke interesser som skal prioriteres, og hvilke tiltak som mest effektivt sikrer disse, er vanskelig å besvare. Det første spørsmålet som kan stilles, er derfor om det å unnta «forbigående tap av fremtidsinntekter» er et egnet tiltak, slik førstvoterende i vår dom synes å legge til grunn, jf. bl.a. avsnitt 62 .

For kompliserte spørsmål kan det være grunn til å isolere de ukompliserte elementene: Vi står overfor en skadevoldende handling - vold mot person i en særlig voldsutsatt gruppe, typisk begått i forbindelse med andre straffbare handlinger, sexkjøp eller hallikvirksomhet - og som

\footnotetext{
${ }^{29}$ I rettslitteraturen knyttes reparasjonshensynet gjerne til grunnleggende rettferdighetsbetraktninger i form av likebehandling og utvekslingsrettferdighet, se bl.a. Jan Ove Færstad, Erstatningsansvar for villedende informasjon (Oslo 2014), punkt 4; Anne Marie Frøseth, Skadelidtes egeneksponering for risiko (Bergen 2013), kapittel 3.1; Hagland, kapittel 2.2 og 4.3; Thorson kapittel 2 B og kapittel 4 A II; Bjarte Askeland, Tapsfordeling og regress ved erstatningsoppgjør (Bergen 2006), kapittel 2.
} 
resulterer i tapt inntekt fra en lovlig, skattbar virksomhet. ${ }^{30}$ I vurderingen av om et gitt tap (prostitusjonsinntekter) skal gis erstatningsvern, er det viktig at en ikke mister av syne hva slags ansvarsgrunnlag det her dreier seg om: personskade som følge av forsettlig voldsutøvelse. ${ }^{31}$ Når erstatningsvernet fastsettes slik flertallet her legger til grunn, får skadevolder en tilfeldig fordel (slik førstvoterende selv også fremhever i avsnitt 54), ikke ulikt gruppevoldtektsrabatt-dommen, jf. Rt. 2008 s. 65: Denne gangen består «rabatten» i at kortvarige, fremtidige inntekter unntas fra erstatningsoppgjøret fordi inntektene stammer fra prostitusjon. Det er altså ikke en grupperabatt, men en rabatt som skyldes at voldsofferet arbeider som prostituert - intet annet. ${ }^{32}$

Og så kommer det vanskelige: Denne lovlige, skattbare inntekten stammer fra arbeid i prostitusjonsmarkedene, som bringer med seg mange, svært alvorlige samfunnsproblemer. ${ }^{33} \mathrm{Da}$ hjelper det lite for den enkelte skadelidte at synet på prostitusjon har endret seg: fra moralsk fordømmelse av «syndige» kvinner til at det er sexkjøperen som har et holdningsproblem. Prostitusjonsmarkedene er uønsket sett fra samfunnets side - og i dag med en mer graverende begrunnelse enn tidligere: fra borgerlig moralsk fordømmelse av «syndige» kvinner til menneskehandel og annen organisert kriminalitet. Lovgiveren har valgt å treffe en rekke tiltak uten at erstatningsvernet er vurdert.

Dersom inntektstypen skal unntas retten til erstatning, bør det være et lovgivervalg. En instrumentell tilnærming til erstatningsvernet ved personskade - som langt på vei synes å fortrenge erstatningsrettens grunnleggende reparasjonshensyn - er i seg selv et verdivalg som etter min mening bør ligge hos lovgiver. Det er tale om en form for fordelingsrettferdighet hvor enkelte tapstyper unntas erstatningsvern basert på verdioppfatninger om hva som «fortjener rettsordenens beskyttelse». Fordelingsrettferdighet (eller «distributive justice») omhandler hva som er rettferdig fordeling av goder i et samfunn, og omtales gjerne som en sosial form for

\footnotetext{
${ }^{30}$ For rene formuestap har Thorson fremhevet at spørsmålet om erstatningsvern ikke kan «sjaltes helt ut fra de andre spørsmålene om hva som er ansvarsbetingende atferd», se Thorson side 77. Grunnen er at når det kommer til rene formuestap, så vil spørsmålet om erstatningsvern gjerne falle sammen med spørsmålet om hvilken atferd som skal anses som culpøs - altså hvordan en atferdsnorm skal etableres. Synspunktet har vunnet tilslutning i rettslitteraturen, se Hagstrøm/Stenvik kapittel 3.2.2 og Wilhelmsen/Hagland kapittel 4.3.3.

${ }^{31}$ Prostituerte kan selvsagt bli utsatt for personskade på annet vis, eksempelvis trafikkskade.

${ }^{32}$ Dommen er omtalt $\mathrm{i}$ leder om individuelt oppreisningsansvar for seksuell krenkelse.

${ }^{33}$ Se eksempelvis Rapport 0214/30 Vistas analyse: «Evaluering av forbudet mot kjøp av seksuelle tjenester».
} 
rettferdighet. I erstatningsrettslig grunnlagsteori anses gjerne fordeling av erstatningsvern, og dermed retten til erstatning, som en form for fordelingsrettferdighet. ${ }^{34}$

Spørsmålet om hvilke virkninger et svekket erstatningsvern for prostitusjonsinntekter faktisk har, og om det er et egnet tiltak, krever dessuten flere analyseverktøy enn det en høyesterettsdom gir rom for. Flertallet synes å legge til grunn at kravet om erstatning for fremtidige inntektstap ville stått sterkere dersom tapsperioden hadde vært lengre (avsnitt 38). Samtidig ville da de etiske og samfunnsmessige motforestillingene ha vært mer tungtveiende. Hvordan tapsperiodens lengde skal balanseres mot virkningene av et svekket erstatningsvern, kan vanskelig utledes av dommen.

Og erstatningsvernet må i sin alminnelighet utformes slik at det ikke kommer i strid med lovbestemte diskrimineringsgrunnlag (se punkt 1). En punktuell utvikling av erstatningsvernet, basert på enkeltsaker som kommer opp for domstolen, er neppe den fremgangsmåten som er best egnet til å overskue hvilke regelvirkninger som akkumuleres på et mer overordnet nivå. En fremgangsmåte basert på at en vurderer om enkeltinteresser «fortjener rettsordenens beskyttelse», medfører snarere fare for at en overser strukturelle virkninger av at erstatningsvernet ved personskade perforeres, herunder eventuelle diskriminerende virkninger, fordi saksområder hvor kvinner er typiske skadelidte, unntas fra erstatningsvern, slik at kvinner får en svakere erstatningsrettslig stilling enn menn.

En instrumentell tilnærming er at en må gjøre seg opp en mening om hvilke interesser som skal beskyttes og hvordan. ${ }^{35}$ Mens domstolen langt på vei er prisgitt hvilke krav, grunnlag og bevis som partene i et sivilt søksmål velger «å bringe til torgs», står lovgiveren fritt til å vurdere et bredere sammensatt rettsgrunnlag, og til å foreta nærmere utredninger når det skal prioriteres i spenningsfeltet mellom ulike samfunnsinteresser. Slik jeg ser det, svekker domstolens

\footnotetext{
${ }^{34}$ Se eksempelvis John Gardner, «What is Tort Law for? Part 2. The Place of distributive justice», i Philosophical Foundations of The Law of Torts, John Oberdiek (red.), Oxford: Oxford University Press 2014.

${ }^{35}$ I Rt. 2015 s. 276 (Bori I) avsnitt 26 og HR-2017-1834-A avsnitt 37 fremheves at en må ta stilling til «de interesser som beskyttes og håndhevingssynspunkter».
} 
premisstilgang sannsynligheten for at spørsmålet om erstatningsvern avgjøres på riktig og legitimt grunnlag. ${ }^{36}$

Samtidig har domstolene en selvstendig plikt til å sørge for at den alminnelige erstatningsrettens regelinnhold og regelanvendelse ikke kommer i strid med Norges folkerettslige forpliktelser, jf. Grl. § 92 og HR-2016-2554-P Holship. ${ }^{37}$ I 2017-dommen underbygger flertallet sine synspunkter på prostitusjonsmarkedene ved å vise til en evalueringsrapport om forbudet mot sexkjøp fra Vista Analyse. ${ }^{38}$ Med henvisning til rapporten legges det blant annet til grunn at erstatningsvern for prostitusjonsinntekter kan «bidra til en alminneliggjøring av sterkt uønsket virksomhet og motvirke de dempende effekter kriminaliseringen av slike kjøp synes å ha hatt på etterspørselen etter seksuelle tjenester», samt at «prostitusjonsmarkedet synes å dreie mot de steder der rammevilkårene er best», jf. særlig dommens avsnitt 57-61.

Dersom en anlegger en instrumentell tilnærming til erstatningsvernet, er det også en annen del av rapporten som peker seg ut som særlig relevant, jf. punkt 11.3: «Vold - en del av prostitusjonsmarkedet». Mot denne bakgrunn er det relevant å stille spørsmål om hvorvidt særlig to bestemmelser i KDK kan gi grunnlag for andre resultater enn det Høyesterett har kommet til i nyere rettspraksis, nemlig artikkel 1 som skal sikre at kvinner ikke diskrimineres på grunnlag av kjønn, og artikkel 6 som forplikter konvensjonsstatene til å «treffe alle tiltak som er nødvendige [...] for å bekjempe alle former for handel med kvinner og utnyttelse av kvinner gjennom prostitusjon». Spørsmålet drøftes i punkt 4.2.

\subsection{Erstatningsvern ved skader i tilknytning til fødsel av uønskede barn}

Til analysen av om Høyesteretts tilnærming til erstatningsvern ved personskade i tilstrekkelig grad ivaretar kvinners erstatningsrettslige stilling på saksområder hvor kvinner er typiske skadelidte, er også en annen dom sentral: Rt. 2013 s. 1689 (fostervannsprøve). En kvinne krevet erstatning for egen psykisk skade etter manglende helsehjelp i forbindelse med

\footnotetext{
${ }^{36}$ Om gjeldende rett og legitimt premisstilfang, se Jan Fridthjof Bernt, «Den dynamiske dimensjonen i rettskildelæren», i «Nybrott og odling». Festskrift til Nils Nygaard på 70-årsdagen 3. april 2002 (Bergen 2002), s. 259-272.

${ }^{37}$ Se nærværende fremstilling punkt 1.

${ }^{38}$ Rapport 0214/30 Vistas Analyse: «Evaluering av forbudet mot kjøp av seksuelle tjenester», utført på oppdrag fra Justis- og beredskapsdepartementet i 2014.
} 
familieplanlegging. Da kvinnen ble gravid med sitt fjerde barn, ba hun om at fosteret ble undersøkt. Familien hadde allerede tre små barn, hvorav to tvillinger med sterkt nedsatt funksjonsevne, og ville ikke tåle merbelastningene dersom det skulle vise seg at også det nye barnet ikke var funksjonsfriskt. Ifølge retningslinjene for fostervannsdiagnostikk tilsa kvinnens livssituasjon at hun skulle ha tilbud om fostervannsprøve. Det fikk hun ikke. Barnet som ble født, hadde Downs syndrom. I etterkant utviklet kvinnen en psykisk lidelse som ble ansett å følge av svikten i helsehjelp. Høyesteretts flertall på tre dommere kom til at psykiske skader med så nær tilknytning til fødselen av et barn ikke bør undergis økonomiske mål, og kravet var derfor ikke erstatningsvernet (avsnitt 40).

Også her er det interessant å ta utgangspunkt i spennet mellom flertallets og mindretallets begrunnelse. For mens flertallets argumentasjon primært bygges rundt fødselen av det uønskede barnet (avsnitt 24), er mindretallets begrunnelse bygget opp rundt et annet vurderingstema: mors psykiske skade som følge av manglende helsehjelp (avsnitt 48).

Sentralt i flertallets votum er «rettskilder som belyser rekkevidden av det erstatningsrettslige vernet når det fødes et barn, til tross for at medisinsk behandling skulle forhindret fødselen» (avsnitt 24). Førstvoterende tar utgangspunkt i en NOU om pasientskadeerstatning, hvor det er lagt til grunn at «krav som følge av» at det fødes et barn etter et mislykket inngrep, ikke er vernet. ${ }^{39}$ Førstvoterende fremhever at uttrykket «krav som følge av» har en videre rekkevidde enn eksemplene som er gitt i NOU-en, nemlig oppfostringskostnader knyttet til uønskede barn (avsnitt 25-27).

En dom som derfor blir sentral i votumet, er Rt. 1999 s. 208 (sterilisering). Her søkte en far erstatning for oppfostringskostnadene til sitt eget barn, et barn som var blitt til etter et mislykket steriliseringsinngrep. Dommen omhandler en gitt økonomisk interesse: oppfostringskostnadene. Det er altså tale om erstatning for utgifter knyttet til at et barn blir født, og en enstemmig Høyesterett er tydelig på at avgjørelsen innebærer et verdivalg når det legges til grunn at det er «tale om en interesse som [...] ikke bør undergis en vurdering med økonomiske mål» (side 207). I dommen fra 2013 slutter førstvoterende seg til verdivalget og fremhever at løsningen må bli

\footnotetext{
${ }^{39}$ NOU 1992: 6 Erstatning ved pasientskader, punkt 4.4.1.
} 
den samme også når barnet har nedsatt funksjonsevne (avsnitt 30-31). Deretter legger førstvoterende til grunn at mors psykiske skade har «nær tilknytning til fødselen av et barn med Downs syndrom» (avsnitt 35). Spørsmålet blir deretter «om psykiske skader med en så nær tilknytning til fødselen av et barn har erstatningsrettslig vern» (avsnitt 36) - et spørsmål som besvares negativt. I begrunnelsen vises det til de hensynene som er utviklet «rundt krav om erstatning for uønsket fødsel», herunder at det for barnet er belastende å anses som en «skade», og at det kan oppstå vanskelige avgrensnings- og bevisproblemer. Etter å ha konstatert at mors psykiske skade ikke er har erstatningsvern etter norsk rett, konstaterer førstvoterende at manglende fostervannsprøve ikke utgjør en krenkelse av EMK (avsnitt 42-44).

Mindretallet tar utgangspunkt i et annet vurderingstema for sin drøftelse av spørsmålet om erstatningsvern: mors psykiske skade som følge av manglende helsehjelp i forbindelse med familieplanlegging. Kort oppsummert begrenser mindretallet prejudikatsvirkningen av steriliseringsdommen til å omhandle utgifter til oppfostring av et uønsket barn (avsnitt 48). Samtidig leses forarbeidene på en annen måte enn førstvoterende; uttalelsene ses ikke å være til hinder for erstatning som følge av svikt i helsehjelp i forbindelse med familieplanlegging. Mindretallet vurderer også de reelle hensynene på en annen måte; erstatning til mor anses ikke som problematisk for barnet, og avgrensnings- og bevisproblemer anses ikke på avgjørende måte å tale mot erstatningsvern. Når det gjelder forholdet til EMK, slutter mindretallet seg til førstvoterendes vurdering.

Verken i flertallets eller mindretallets votum presiseres ytterligere hvordan det overordnede vurderingstemaet for erstatningsvern kan operasjonaliseres. I rettslitteraturen har særlig flertallets begrunnelse allerede blitt gjenstand for kritisk behandling. ${ }^{40}$ I det følgende skal vi se på vurderingsmomenter som typisk er relevante i en erstatningsvurdering: tapssituasjonen, pliktbruddet, hvilke interesser som beskyttes, og effektivitetsbetraktninger.

\footnotetext{
${ }^{40}$ Se Knut Martin Tande, «Høyesterett som prejudikatsdomstol innen erstatningsretten - foredling eller friere rettspolitikk», Tidsskrift for erstatningsrett, forsikringsrett og trygderett, 2016 nr. 1, s. 30-68; Randi Sigurdsen, «Rt. 2013 s. 1689 Å dømme i verdispørsmål», Tidsskrift for familierett, arverett og barnevernrettslige spørsmål 2015, s. 137-153.
} 
Dersom vi først ser på tapssituasjonen, er barnefødsel det farligste de fleste norske kvinner gjør i løpet av livet, nest etter selv å bli født. Om svangerskap og fødsler viser seg å være enkle eller kompliserte, korresponderer ikke med merkelappene «ønsket/planlagt» eller «uønsket/ikkeplanlagt». I et kvinneperspektiv er det viktig at erstatningsvernet for kvinners helseskader ikke uløselig knyttes til om barnet er ønsket eller ikke. I de fleste tilfeller vil det nok være en kortslutning å legge til grunn at det å unnta mors psykiske skader fra et erstatningsvern er «den beste løsningen, i relasjon til barnets, foreldrenes og samfunnets interesser generelt vurdert», som det heter i Rt. 1999 s. 203 (på s. 207). Dersom mors helseskader medfører at hun ikke kan arbeide, hjelper det neppe barnet, foreldrene eller samfunnet at hun ikke tilkjennes erstatning og dermed også får dårligere økonomi enn hun ville hatt dersom helseskaden var erstatningsvernet.

Pliktbruddet vi her står overfor, er svikt i helsehjelp. Det følger av pasientskadeloven $\S 2$ første ledd bokstav a at den som har lidt tap på grunn av pasientskade, har krav på erstatning når skaden skyldes «svikt ved ytelsen av helsehjelp, selv om ingen kan lastes». I utgangspunktet står vi overfor et pliktbrudd som lovgiveren har valgt å verne skadelidte mot gjennom pasientskadeloven. Plikten korresponderer med kvinnens rett til selvbestemt svangerskapsavbrudd, som vi kommer tilbake til straks nedenfor.

I spørsmålet om hvilke interesser som beskyttes, deler flertallet og mindretallet seg. Etter min mening viser dommen fra 2013 at det tydelige verdivalget som tas i steriliseringsdommen - at konsekvensene av at et uønsket barn blir født, ikke er en erstatningsvernet interesse - er mer sammensatt enn det en får inntrykk av etter å ha lest domsbegrunnelsen. Fostervannsprøvedommen viser at uønskede barn ikke representerer én økonomisk interesse; her er det tale om erstatning for mors helseskader, ikke oppfostringskostnader. Graver påpekte allerede i 2012 at interessene knyttet til familieplanlegging er mange, og benyttet et annet eksempel for å understreke sitt poeng: Hva hvis mor allerede har barn og dør under svangerskapet på grunn av en komplikasjon? ${ }^{41}$ Skal vi nekte de etterlatte barna forsørgertapserstatning fordi svikt i helsehjelp har ført til at hun har båret frem et barn, og at det kom et nytt barn til verden? Graver påpeker at det å si at «et nytt liv uten videre begrunnelse oppveier alle andre tap, verken er logisk

\footnotetext{
${ }^{41}$ Hans Petter Graver, «Rettferdighet som juridisk argument - kan graviditet sammenlignes med fysisk skade», Tidsskrift for erstatningsrett, forsikringsrett og trygderett 2012, s. 1-4.
} 
eller moralsk nødvendig». Det er vanskelig å få øye på hvorfor det er moralsk, logisk eller erstatningsrettslig nødvendig å uthule kvinners rett til erstatning dersom hennes fysiske eller psykiske skade «har nær tilknytning til fødselen av et barn» (Rt. 2013 s. 1689 avsnitt 40). Etter min mening bør mors skader som følge av manglende helsehjelp anses som en selvstendig skadelidt interesse.

Anses mors skade som følge av manglende helsehjelp som en selvstendig skadelidt interesse, blir spørsmålet hvordan operasjonaliseringen av erstatningsvernet ved personskade kan ivareta kvinners rett til helsehjelp og familieplanlegging. Spørsmålet er hvordan effektivitetsbetraktninger kan knyttes til beskyttelse av denne skadelidte interessen. Retten til helsehjelp ved familieplanlegging har vært helt sentral i kampen for kvinners rettigheter, ${ }^{42}$ og den er anerkjent i norsk lov gjennom lovfesting av kvinners rett til selvbestemt abort, jf. lov om svangerskapsavbrudd $\S 2 .{ }^{43}$ Slik jeg ser det, er det en mangel ved både flertallets og mindretallets votum at denne lovbestemte rettigheten ikke inngår som en tolkningsfaktor i fastleggingen av erstatningsvernet. ${ }^{44}$ I fastleggingen av erstatningsvern for mors helseskader som følge av manglende helsehjelp i forbindelse med familieplanlegging fremstår den lovbestemte retten til svangerskapsavbrudd som en sentral tolkningsfaktor. Bestemmelsen i $\S 2$ fastsetter at dersom et svangerskap fører til «alvorlige vansker» for en kvinne, så har hun krav på råd «for selv å kunne treffe det endelige valget». I forarbeidene til loven fremheves at det er «barnets og morens felles framtid det dreier seg om, ikke morens interesser kontra fosterets». ${ }^{45}$ Det kan nevnes at også abortloven fra 1960 - før kvinner hadde rett til selvbestemt abort - ga hjemmel for at en kvinne i visse situasjoner kunne få innvilget svangerskapsavbrudd. I vurderingen skulle det tas hensyn til «om kvinnen kan få [en] fysisk eller psykisk helseknekk dersom hun fullfører svangerskapet». ${ }^{46}$

\footnotetext{
${ }^{42}$ Se eksempelvis https://snl.no/abortkampen (sist besøkt 3. april 2017).

${ }^{43}$ Lov 13. juni $1975 \mathrm{nr} .50$ om svangerskapsavbrudd.

${ }^{44}$ Vurderingstemaet som flertallet i Høyesterett formulerer i HR-2017-2352-A (prostitusjonsinntekter), med henvisning til Hagstrøm/Stenvik, er tydelig inspirert av PEL bok VI kapittel 2, art. 2:101 litra c som bestemmer at en skade er «legally relevant» dersom tapet eller skaden «results from a violation of an interest worthy of legal protection», jf. litra c. I denne sammenhengen kan det være verdt å merke seg at PEL art. 2:101 også uttrykkelig bestemmer at en skade er «legally relevant» dersom tapet eller skaden «results from a violation of a right otherwise conferred by the law», jf. litra $b$.

${ }^{45}$ Ot.prp. nr. 38 (1974-75) punkt V.

${ }^{46}$ Ot.prp. nr. 38 (1974-75) punkt V.
} 
I dommen drøftes EMK som selvstendig grunnlag, i forlengelsen av fastleggelsen av erstatningsvernet etter norsk rett. Spørsmålet om og hvordan Norges menneskerettslige forpliktelser slik de er inkorporert i norsk rett gjennom mrl. § 2, kan inngå som tolkningsfaktor i fastleggelsen av erstatningsvernet etter norsk rett, er ikke tema. Som ledd i drøftelsen av hvordan operasjonaliseringen av erstatningsvernet ved personskade kan ivareta kvinners rett til helsehjelp og familieplanlegging, synes det imidlertid også her relevant å stille spørsmål om KDK kan gi grunnlag for andre resultater enn det Høyesterett har kommet til i nyere rettspraksis, dersom KDK inngår som tolkningsfaktor ved fastleggelse av erstatningsvernet ved personskade. Dette er tema i neste avsnitt, se særlig punkt 4.2.2.

\section{Om anvendelsen av KDK på saksområder hvor kvinner er typiske skadelidte}

\subsection{Folkerettslig påvirkning av erstatningsretten og metodeutfordringer ved bruk av KDK}

Forholdet mellom norsk erstatningsrett og Norges menneskerettslige forpliktelser er i mindre grad avklart. Generelt finnes det lite rettspraksis og få rettsvitenskapelige arbeider om temaet. ${ }^{47} \mathrm{I}$ den grad Norges menneskerettslige forpliktelser hittil har vært et erstatningsrettslig diskusjonstema, er det med utgangspunkt i Den europeiske menneskerettighetskonvensjon (EMK). ${ }^{48}$
Også til diskusjonen om det er rom for et kvinneperspektiv i erstatningsretten, kan EMK og en rikholdig rettspraksis fra Den europeiske menneskerettighetsdomstolen (EMD) gi verdifulle bidrag. Som eksempel på EMKs gjennomslagslagskraft på et saksområde som har betydning for kvinners erstatningsrettslige stilling, kan nevnes Rt. 2013 s. 588 (besøksforbud). Dommen omhandler i hovedsak statens positive plikt til å verne personer mot skadevoldende handlinger fra andre, og det vil typisk si kvinner i forhold til voldelige menn. ${ }^{49}$

\footnotetext{
${ }^{47}$ Sentral er Rt. 2013 s. 588 (besøksforbud). Blant rettsteoretiske arbeider kan særlig fremheves Hjelmeng. Se også Bjarte Thorson, «Chapter 12 Damages for the Infringements of Human Rights Under Norwegian Law», i Damages for Violations of Human Rights, E. Baginska (red.), Ius Comparatum - Global Studies in Comparative Law 9 (Thorson, Damages), samt Bjarte Askeland og Jørgen Aall, «Statens oppreisningsansvar ved menneskerettighetsbrudd», Tidsskrift for erstatningsrett, forsikringsrett og trygderett 2017 nr. 1, s. 3-6. Men også i alminnelige erstatningsrettslige fremstillinger er forholdet kort berørt, se Hagstrøm/Stenvik kapittel 2.2, Kjelland kapittel 3.3 og Wilhelmsen/Hagland kapittel 2.8.3. Annerledes er dette i svensk erstatningsrett hvor en har lenge diskutert forholdet mellom erstatningsrett og menneskerettighetene, se bl.a. Håkan Andersson, Ersättningsproblem $i$ skadeståndsrätten - Skadeståndsrättsliga utvecklingslinjer, Bok III, Iustus förlag 2017, kap. 5.

${ }^{48}$ Menneskerettighetskonvensjonen ble allerede i 1999 gjennomført som norsk lov ved menneskerettsloven (mrl.), jf. § 2. Samtidig er mange av bestemmelsene i Grunnlovens menneskerettighetskatalog utformet med EMK som forbilde, jf. Grl. kapittel E. Menneskerettighetskatalogen ble vedtatt i forbindelse med grunnlovens 200-årsjubileum i 2014 .

${ }^{49}$ I dommen pådømmes kun spørsmålet om det foreligger brudd på EMK (og rekkevidden av konvensjonsbestemmelsene), men i rettslitteraturen er avgjørelsen tatt til inntekt for at konvensjonsbrudd kan utgjøre et selvstendig ansvarsgrunnlag for staten, jf. særlig førstvoterendes uttalelse: «Jeg er kommet til at det
} 


\section{Det betyr imidlertid ikke at EMK er det eneste konvensjonsgrunnlaget som er relevant for}

diskusjonen om og hvilket rom det er for kvinneperspektivet i erstatningsretten. Et formål med denne artikkelen er å løfte frem en annen konvensjon som også gjelder som norsk lov: kvinnediskrimineringskonvensjonen (KDK). Til tross for at konvensjonen er gjort til norsk lov gjennom mrl. § 2, og dermed har tilsvarende rettskildemessige status som EMK, fremstår KDK som et tilnærmet ukjent rettsgrunnlag.

Vi kan gjøre følgende faktiske observasjon: KDK påberopes (for) sjelden i norske rettssaler - dette gjelder også for erstatningssaker. ${ }^{50}$ I høyesterettspraksis hittil er KDK tema i kun én sivil sak. ${ }^{51}$ Dersom antall saker i rettspraksis hvor konvensjonen er påberopt, kan leses som en indikator på hvilken kunnskap rettsaktørene har om konvensjonen, synes det som (for) få er klar over at KDK gjelder som norsk rett. Det til tross for at det snart er ti år siden konvensjonen ble tatt inn i menneskerettsloven med forrang foran alminnelig lov, jf. mrl. $\S 3$. Og det til tross for at lovgiveren ved inkorporeringen av kvinnediskrimineringskonvensjonen mente at med «det sterke signalet nasjonalt og internasjonalt ei inkorporering med forrang vil sende, blir òg medvitet om likestillingsspørsmål og kvinners rettar styrkt». ${ }^{52}$ I sin nyeste landrapport, fra november 2017, gjentok CEDAW: «[I]ts previous concern about the general lack of awareness of the Convention and its Optional Protocol in the State party, including amongst Government and law enforcement officials, and the judiciary.»» ${ }^{53}$

I dette avsnittet skal vi se nærmere på om og eventuelt hvordan KDK gir grunnlag for styrking av kvinners erstatningsrettslige stilling. Det følger av KDK artikkel 1 at uttrykket «diskriminering av kvinner» omfatter

«enhver kjønnsmessig sondring, utelukkelse eller innskrenkning som har som virkning eller formål å svekke eller utelukke anerkjennelsen, utnyttelsen eller utøvelsen av kvinners menneskerettigheter og grunnleggende friheter på det politiske, økonomiske, sosiale, kulturelle, sivile eller ethvert annet område, på grunnlag av likestilling mellom menn og kvinner og uten hensyn til ekteskapelig status».

Konvensjonen forbyr både direkte og indirekte diskriminering, jf. «virkning eller formål».

foreligger ansvarsgrunnlag» (avsnitt 22), se blant annet Hjelmeng punkt 2, Wilhelmsen/Hagland punkt 2.8 og Thorson, Damages. Samtidig kan det synes som Høyesterett er noe tilbakeholden i spørsmålet om statens erstatningsansvar, jf. HR-2016-2195-S. Statens ansvar for brudd på EMK er like fullt ikke kontroversielt. Indirekte kan også konvensjonen få betydning mellom private (horisontal virkning) ved at EMK får betydning for fastleggelsen av erstatningsrettslige reglers innhold. Tydelige eksempler fra nyere rettspraksis er Rt. 2015 s. 746 (fotballklubb) og Rt. 2014 s. 1170 (ambulansesjåfør).

${ }^{50}$ Søkeordet «kvinnekonvensjonen» i Lovdata gir kun åtte treff i rettspraksis totalt, se https://lovdata.no/pro/\#result\&id=2223\&q=kvinnekonvensjon* (sist besøkt 01.08.2018).

${ }^{51} \mathrm{Se}$ https://lovdata.no/pro/\#result\&id=2223\&q=kvinnekonvensjon* (sist besøkt 01.08.2018).

52 Jf. lov om endringar i menneskerettsloven mv. (inkorporering av kvinnediskrimineringskonvensjonen) 19. juni 2009 nr. 80 og Ot.prp. nr. 93 (2008-2009) punkt 7.3.

${ }^{53}$ Se «Concluding observations on the ninth periodic report of Norway», datert 17. november 2017, $\mathrm{CEDAW} / \mathrm{C} / \mathrm{NOR} / \mathrm{CO} / 9$ punkt D. 
Spørsmålet er om KDK kan gi grunnlag for andre resultater enn det Høyesterett har kommet til i nyere rettspraksis, dersom konvensjonen inngår som tolkningsfaktor ved fastleggelse av erstatningsvernet ved personskade. ${ }^{54}$ Også her vil analysen ta utgangspunkt i den rettsutviklingen av erstatningsvern for personskade på saksområder hvor kvinner er typiske skadelidte, som forannevnte dommer representerer (se punkt 3).

Anvendelsen av KDK som tolkningsfaktor medfører imidlertid enkelte særlige metodiske utfordringer som hittil ikke er løftet frem i en erstatningsrettslig sammenheng.

Metodeproblemene knytter seg dels til konvensjonsbestemmelsenes utforming og status som rettsgrunnlag: Normene er så generelt utformet at det kan være vanskelig å lese ut hvilke forpliktelser staten har, hva som skal til for å etablere et diskrimineringsgrunnlag, og hvilke individuelle rettigheter som kan utledes. I forarbeidene til inkorporeringen av KDK i menneskerettsloven fremheves det at innholdet er «vagt og kompromisspreget», og at «i den grad konvensjonene er av rettslig karakter», er innholdet «svært vage rettslige standarder som i økende grad tolkes dynamisk og utviklingspreget med større intensitet». ${ }^{55}$

Til gjengjeld gir FNs kvinnediskrimineringskomité (CEDAW) i sine generelle anbefalinger (General Comments) forholdsvis omfattende retningslinjer for tolkningen av konvensjonsbestemmelsene. Eksempelvis følger kravet til «effective reparation» ved konvensjonsbrudd ikke av konvensjonen selv, men er nedfelt bl.a. i CEDAW/GC/33 On Women's Access to Justice og CEDAW/GC/35 On Gender Based Violence Against Women part III, E. art. 33 litra a. CEDAWs General Comments har stor betydning for hvordan KDKs folkerettslige innhold fastsettes. Samtidig er det vanskelig å tegne et enhetlig bilde av hvilken rettskildemessig betydning CEDAWs General Comments kan tillegges i norsk rett. Det er på det rene at denne formen for komitéuttalelser ikke generelt er folkerettslig bindende, jf. bl.a.

\footnotetext{
${ }^{54}$ Anvendelsen av KDK i en erstatningsrettslig sammenheng reiser i sin alminnelighet spørsmål om konvensjonens betydning for statens forpliktelser overfor borgerne (vertikal virkning) og konvensjonens betydning i saker mellom borgerne (horisontal virkning). Tema i denne artikkelen er ikke spørsmål om statens eventuelle erstatningsansvar for brudd på konvensjonenes forpliktelser. I denne artikkelen er det stilt spørsmål om og hvordan KDK kan inngå som tolkningsfaktor ved fastleggelsen av erstatningsvern ved personskade. Dette er spørsmål som relaterer seg til om og i hvilken grad staten, nærmere bestemt Høyesterett, har en positiv forpliktelse til å sørge for at innholdet $\mathrm{i}$ domstolskapt erstatningsrett utvikles slik at innholdet i ulovfestet norsk rett ikke kommer i strid med diskrimineringsforbudet i KDK. Indirekte kan konvensjonen dermed få betydning for erstatningssaker mellom borgerne (som kan ses som en form for horisontal virkning).

${ }^{55}$ Ot.prp. nr. 93 ( 2008-2009 ) s. 35.
} 
plenumsdommene Rt. 2012 s. 1985 og Rt. 2015 s. 1388. Ser en hen til forarbeidene til inkorporeringen av KDK i menneskerettsloven og rettspraksis, synes det lagt til grunn at uttalelsenes vekt må bedømmes konkret og vil variere både med hensyn til hvor presist rettslig innhold uttalelsene har, og hvor langt anvendelsen av uttalelsene passer inn i det øvrige rettskildebildet og på norske forhold, jf. Ot.prp. nr. 93 (2008-2009) s. 32 og Rt. 2009 s. 1261.

I forarbeidene til inkorporeringen av KDK i menneskerettsloven er den rettskildemessige statusen for CEDAWs General Comments omtalt slik:

«Når det gjeld dei generelle tilrådingane som kvinnediskrimineringskomiteen kjem med, og som gir uttrykk for komiteens syn på korleis føresegnene i konvensjonen skal tolkast, må det truleg leggjast stor vekt på desse i ein reint folkerettsleg samanheng. Kva innverknad dei har i ei konkret norsk sak, vil kunne variere alt etter kor klar fråsegna er, og i kva grad den konkrete saka er identisk med dei situasjonane komiteen truleg har hatt for auge under utarbeidinga.»

Forarbeidsuttalelsene synes å være i overensstemmelse med den alminnelige oppfatningen i folkerettsteorien om at statenes plikt til å opptre konvensjonslojalt i sin tolkning også tilsier at statene bør legge stor vekt på FN-komitéenes syn på hvordan konvensjonene er å forstå, jf. Wien-konvensjonen av 1969 om traktatretten artikkel $31 \mathrm{nr} .1$ om at traktater skal tolkes «in good faith». ${ }^{56}$ Norge har ikke ratifisert Wien-konvensjonen, men traktaten anses å gi uttrykk for folkerettslig sedvane.

Høyesterett har hittil ikke uttalt seg uttrykkelig om anvendelsen av CEDAWs General Comments i norsk rett. Men i Rt. 2009 s. 1261, som er en dom som i første rekke handler om FNs barnekomités General Comments, viser førstvoterende til de ovenfor siterte forarbeidsuttalelsene om CEDAW. Når førstvoterende deretter taler generelt om «overvåkningsorganenes uttalelser», synes omtalen også å omfatte CEDAW General Comments. Førstvoterende uttaler at

«det formelle grunnlaget for at uttalelsen er avgitt, har en viss betydning for den vekt den skal tillegges. Det avgjørende vil likevel være hvor klart den må anses å gi uttrykk for overvåkingsorganenes forståelse av partenes forpliktelser etter konvensjonene. Særlig må man vurdere om uttalelsen må ses som en tolkingsuttalelse, eller mer som en tilråding om optimal praksis på konvensjonens område. Dernest må man vurdere om uttalelsen passer på det aktuelle faktum og rettsområde. Dette siste er av særlig betydning ved generelle uttalelser som ikke er knyttet til enkeltsaker eller landrapporter, og som derfor ikke har vært gjenstand for dialog mellom komitéen og den berørte staten» (avsnitt 44).

Hva gjelder forholdet mellom generelle uttalelser og enkeltsaker, kan vi merke oss at CEDAW har kompetanse til å treffe avgjørelser i individuelle klagesaker, jf. tilleggsprotokollen til KDK fra 1999 om individuell klagerett. Men selv om Norge ratifiserte protokollen 5. mars 2002, er hittil ingen individuelle klagesaker mot Norge realitetsbehandlet av CEDAW. Når det gjelder forholdet mellom generelle uttalelser og landrapporter, har CEDAW utarbeidet i alt ni landrapporter om Norge; den siste rapporten er fra november 2017 (CEDAW/C/NOR/9). ${ }^{57}$

Når den alminnelige erstatningsrettens regelinnhold skal fastsettes, må det derfor konkret vurderes hvilket tolkningsbidrag de ulike uttalelsene i CEDAWs General Comments kan gi.

\footnotetext{
${ }^{56}$ Se blant annet Arnfinn Bårdsen, «Betydningen i norsk rett av FN-komiteenes uttalelser i individuelle klagesaker», i Tidsskrift for Rettsvitenskap 2017 nr. 2-3, s. 160-187 (heretter Bårdsen), punkt 4 og punkt 6; Tone Linn Wærstad, «Protecting Muslim Minority Women's Human Rights at Divorce», Oslo Legal Studies Volume 2, Nomos, pkt. 2.4. 57 Om statsrapportering, se Erik Møse, Menneskerettigheter (Oslo 2002), kapittel 7.5.2, og Njål Høstmælingen, Internasjonale menneskerettigheter, 2. utgave (Oslo 2012), kapittel 18.4.
} 
Samtidig må en ta følgende i betraktning: KDKs diskrimineringsforbud stiller krav til erstatningsrettens regelinnhold; det er KDK med sitt folkerettslige innhold som gjelder som norsk lov, jf. mrl. $\S 2$, og at CEDAWs General Comments har stor betydning for å finne frem til hva som er riktig folkerettslig tolkning av konvensjonen. ${ }^{58}$ Retningslinjene er derfor brukt $\mathrm{i}$ artikkelens drøftelser.

Mot denne bakgrunnen tar artikkelens videre analyser for seg spørsmålet om og hvordan KDK kan inngå som tolkningsfaktor ved fastleggelse av erstatningsvernet ved personskade. Vi skal først ta for oss de bidragene til rettsutviklingen av erstatningsvern for personskade som dommene om erstatningsvern for prostitusjonsinntekter representerer, jf. punkt 4.2.1.

\subsection{Kan KDK gi grunnlag for å styrke kvinners erstatningsrettslige stilling i skadetilfellene?}

\subsubsection{KDK og personskader som resulterer i tapte prostitusjonsinntekter}

Prostitusjonsmarkedet er heterogent. Salg av seksuelle tjenester foregår i mange ulike fora og former, og tilbydere av seksuelle tjenester inngår i en sammensatt gruppe med svært ulike livsvilkår. Deler av prostitusjonsmarkedet er det vanskelig å få kunnskap om, og vi har ikke sikker kunnskap om kjønnsfordeling. Samtidig tilsier all sentral forskning og rapportering at det er flere kvinner enn menn arbeider som prostituerte, og samfunnets samlede ressursbruk er innrettet mot at det er et flertall kvinner blant de prostituerte - hjelpetiltak og politiinnsats er tungt innrettet mot kvinner i prostitusjon. Like fullt vet vi at det er langt flere kvinner enn menn i prostitusjon som er ofre for menneskehandel. Og vi vet at prostituerte er en særlig voldsutsatt gruppe. $^{59}$

Mot denne bakgrunn er det særlig to bestemmelser i kvinnediskrimineringskonvensjonen (KDK) som peker seg ut som relevante tolkningsfaktorer i fastleggelse av erstatningsvernet, nemlig artikkel 1 som skal sikre at kvinner ikke diskrimineres på grunnlag av kjønn, og artikkel 6 som forplikter konvensjonsstatene til å «treffe alle tiltak som er nødvendige [...] for å bekjempe alle

\footnotetext{
${ }^{58}$ Se Bårdsen.

${ }^{59}$ Jf. Vista Rapport 2014/30 punkt 11.3.
} 
former for handel med kvinner og utnyttelse av kvinner gjennom prostitusjon». Spørsmålet er om bestemmelsene har en gjennomslagskraft som gir grunnlag for andre resultater enn det Høyesterett har kommet til, og slik styrke kvinners erstatningsrettslige stilling.

I General Comment no. 35 (2017) har CEDAW klargjort at diskriminering av kvinner som definert i artikkel 1 også omfatter kjønnsbasert vold. Det vil si «violence which is directed against a woman because she is a woman or that affects women disproportionately», og at slik voldsutøvelse innebærer krenkelse av kvinners menneskerettigheter, jf. I, 1. CEDAW fremhever at diskriminering de facto eller de jure er knyttet til ulike faktorer som påvirker kvinners liv deriblant prostitusjon, jf. II, 12. Med hensyn til erstatningsspørsmålet anbefaler CEDAW at statene skal sørge for «effective reparation» til skadelidte kvinner som er ofre for kjønnsbasert vold. Reparasjonen bør blant annet omfatte kompensasjon, og være «adequate, promptly attributed, holistic and proportionate to the gravity of the harm suffered», jf. CEDAW/GC/35 IV, E. 33 litra a. ${ }^{60}$

I lys av disse anbefalingene kan det iallfall stilles spørsmål om den rettslige løsningen som flertallet falt ned på i HR-2017-2352-A (prostitusjonsinntekter), i tilstrekkelig grad stemmer overens med de anbefalinger som CEDAW gir, de konvensjonsforpliktelsene som Norge har påtatt seg, og - ikke minst - gjeldende norsk rett slik denne følger av KDK art. 1 og 6, jf. mrl. § $2 \mathrm{nr}$. 5. Det er en utfordring at konvensjonsforpliktelsene er vagt beskrevet, og det finnes lite praksis som kan bidra til avklaring. Nettopp derfor burde Høyesterett tatt stilling til konvensjonens gjennomslagskraft.

I lys av CEDAWs anbefalinger kan det også være grunn til å løfte frem at norsk lovgiver gjennom voldsoffererstatningsordningen har truffet tiltak for å sikre voldsofre erstatning. Etter lovgivers syn står statens ansvar for å forhindre voldsforbrytelser i en særstilling: «Disse forbrytelsene anses å representere en direkte trussel mot folks liv og helse, og krenker de mest fundamentale rettsgodene i vårt samfunn. Der samfunnet i det enkelte tilfelle ikke lykkes $i$ å forhindre slike handlinger, bør fellesskapet dekke det tap som personskaden fører med seg der dekning for tapet ikke kan oppnås på annen måte» (Ot.prp. nr. 4 (2000-2001) s. 17).

\footnotetext{
${ }^{60}$ Se også CEDAW/GC/33 II A.
} 
Også lovgivningen som kriminaliserer sexkjøp og virksomhet knyttet til prostitusjon, og tillater salg av seksuelle tjenester, bygger på en beskyttelsestanke. ${ }^{61}$ Voldsskadeutvalgets innstilling i NOU 2016: 9 har tittelen «Rettferdighet og forutsigbarhet - voldsskadeerstatning», og tittelen er ment å understreke hva som har vært retningsgivende for utvalgets arbeid. ${ }^{62}$ En instrumentell tilnærming til erstatningsvernets funksjon åpner for å sikre effektiv ivaretakelse av de rettspolitiske utgangspunktene som lovgiveren har stilt seg bak gjennom voldsskadeerstatningsordningen så sent som i 2016. Da er det et paradoks at rettstilstanden etter 2017-dommen medfører at en gruppe som er særlig voldsutsatt, for deler av tapet sitt unntas fra voldsoffererstatningsordningen. ${ }^{63}$ Slik erstatningsvernet tilskjæres i dommen, er det vanskelig å se at en oppnår noen effektivitetsgevinst med hensyn til interesser som lovgiveren her har ment å sikre, og som synes å sammenfalle med interessene som KDK skal ivareta: at særlig voldsutsatte kvinner får en styrket erstatningsrettslig stilling.

\subsubsection{KDK og personskader i forbindelse med uønskede barn}

Spørsmålet blir så om KDK kan gi grunnlag for å styrke kvinners erstatningsrettslige stilling dersom svikt i kvinners rett til helsehjelp og familieplanlegging fører til personskade i forbindelse med fødselen av et uønsket barn.

Ifølge KDK artikkel 12 nr. 1 skal statene treffe alle tiltak som er nødvendige for å avskaffe diskriminering av kvinner på helseområdet; herunder fremheves særlig «hjelp til familieplanlegging». Bestemmelsen må leses i sammenheng med artikkel 16 litra e, om at statene skal treffe alle tiltak som er nødvendige for å avskaffe diskriminering av kvinner blant annet i familieforhold, og især sikre rettighetene til på «fritt grunnlag å treffe en ansvarlig beslutning om antall barn og avstand mellom barnefødsler, og å ha tilgang til [...] midler som setter dem i stand til å utøve disse rettighetene», jf. litra e.

\footnotetext{
${ }^{61}$ Jf. Ot.prp. nr. 48 (2007-2008) og Innst. O. nr. 3 (2008-2009).

${ }^{62}$ Innstillingen er omtalt i dette tidsskiftet på lederplass av professor Ragnhild Hennum, jf. Hennum, «Nytt lovforslag om voldsskadeerstatning», Tidsskrift for erstatningsrett, forsikringsrett og trygderett 2016 nr. 3, s. 177182.

${ }^{63}$ Jf. lov 20. april $2001 \mathrm{nr} .13 \mathrm{om}$ erstatning fra staten for personskade voldt ved straffbar handling (voldsoffererstatningsloven) og rapporten fra Vista Analyse, rapport 2014/30, fra punkt 11.3 «Vold en del av prostitusjonsmarkedet».
} 
I General Comment no. 33 (2015) fremhever CEDAW seks grunnkomponenter som skal sikre kvinners «access to justice» uavhengig av konvensjonslandendes rettslige, sosiale, kulturelle, politiske og økonomiske forhold. Blant grunnkomponentene fremheves at «[p]rovisions of remedies requires that justice systems provide women with viable protection and meaningful redress for any harm they may suffer», jf. CEDAW/GC/33 II A premiss 14 litra e. Etter flertallets votum i Rt. 2013 s. 1689 må det kunne sies at det iallfall ikke fremstår som klart at rettstilstanden for erstatningsvernet for kvinners helseskader er i overensstemmelse med KDK.

\section{Avsluttende betraktninger}

Både Rt. 2013 s. 1689 (fostervannsprøve) og HR-2017-2352-A (prostitusjonsinntekt) er skarpe dissensdommer (3-2). Etter min mening er mindretallets argumentasjon i begge dommer godt forenlig med et kvinneperspektiv, ${ }^{64}$ mens flertallet $\mathrm{i}$ (for) stor grad velger å prioritere andre hensyn - det være seg alt fra vanskelige bevisspørsmål til prioritering av samfunnets overordnede interesser - på bekostning av skadelidte kvinners rett til erstatning som følge av personskade. Spørsmålet om erstatningsvern er i gjeldende rett formulert som et spørsmål «om interessen fortjener rettsordens beskyttelse». ${ }^{65}$ Et så vidt formulert rettsspørsmål åpner for å ivareta mange perspektiver. Hvilket svar vi gir på spørsmålet, handler om holdninger og hvilke perspektiver en velger å prioritere.

Ser vi hen til lovgiverhold, kan vi observere at en i moderne lovgivning har valgt å prioritere et styrket rettsvern for kvinner, jf. eksempelvis skl. § 3-5 annet ledd om oppreisningserstatning ved seksuelle krenkelser og likestillings- og diskrimineringsloven $\S 13$, jf. $\S 38$ om oppreisningserstatning ved trakassering. Selv om «spørsmålet om erstatning [...] avgjøres uavhengig av loven», ${ }^{66}$ bør rettsutviklingen også innenfor den ulovfestede erstatningsretten etterstrebe at prioriteringer som gjøres, og holdninger som legges til grunn, samsvarer med tidsmessige prioriteringer og holdninger som kommer til uttrykk på lovgiverhold. Ikkediskrimineringsprinsippet er en helt grunnleggende verdi i det norske rettssystemet. Prinsippet er derfor grunnlovsfestet i Grl. § 98. Som ledd i begrunnelsen for å grunnlovfeste ikke-

\footnotetext{
${ }^{64}$ Tilsvarende kan sies om HR-2016-2491-A (restitusjon).

${ }^{65}$ HR-2017-2352-A (prostitusjonsinntekt) avsnitt 36 med videre henvisning til Hagstrøm/Stenvik s. 48.

${ }^{66}$ Rt. 1999 s. 203 (sterilisering) på s. 206 og HR-2017-2352-A prostitusjonsinntekter avsnitt 34.
} 
diskrimineringsprinsippet fremhever forarbeidene at grunnlovfestingen vil gi prinsippet «større gjennomslagskraft i rettslig og politisk argumentasjon». ${ }^{67}$

Da er det et paradoks at i saker som omhandler erstatningsvernet for personskader, hvor det er vanskelig å komme utenom et kvinneperspektiv, jf. særlig Rt. 2013 s. 1689 (fostervannsprøve) og HR-2017-2352-A (prostitusjonsinntekter), berøres verken det prinsipielle spørsmålet om det er behov for å styrke kvinners erstatningsrettslige stilling på saksområder hvor kvinner er typiske skadelidte, eller forholdet til kvinnediskrimineringskonvensjonen (KDK). Spørsmålene trenger en ny gjennomtenkning. I den videre utviklingen av erstatningsvern bør en være mer oppmerksom på hvilken betydning perforering av erstatningsvernet ved personskader har for kvinners erstatningsrettslige stilling, og sørge for at kvinner ikke reelt sett får dårligere erstatningsvern for sine personskader - og slik også en svakere erstatningsrettslig stilling - enn menn.

Kvinnediskrimineringskonvensjonen forplikter, jf. mrl. § $2 \mathrm{nr}$. 5. I sin fortolkning av KDK har CEDAW anbefalt at konvensjonsstatene sikrer kvinner «access to all available judicial [...] remedies» (litra a), herunder rett til erstatning, jf. General Comment no. 33 (2015) premiss 19. I forarbeidene til loven som inkorporerer KDK i menneskerettsloven, fremheves at en sikrer at «forbodet mot diskriminering av kvinner vil vere eit sentralt omsyn i lovgivningsarbeidet og forvaltning også i framtida». ${ }^{68}$ Tilsvarende må selvsagt gjelde utviklingen av ulovfestet rett gjennom rettspraksis.

Artikkelens analyser viser at dersom KDK anvendes som tolkningsfaktor i fastleggelsen av erstatningsvernet, kan det bidra til å motvirke faren for at en overser strukturelle og diskriminerende virkninger når erstatningsvernet ved personskade utformes, og slik bidra til å sikre at kvinner får et adekvat erstatningsvern for sine personskader, også på saksområder hvor kvinner er typiske skadelidte. Utfordringen er samtidig at KDK er en konvensjon hvor rettighetene er svakt beskrevet, og det finnes lite praksis. Derfor er det behov for at Høyesterett bidrar til å avklare konvensjonens gjennomslagskraft på saksområder hvor kvinner fremstår som

\footnotetext{
${ }^{67}$ Side 147 med henvisning til NOU 2009: 14 s. 320.

${ }^{68}$ Jf. Ot.prp. nr. 93 (2008-2009) punkt 7.3.
} 
typiske skadelidte. I erstatningsretten representerer anvendelsen av KDK som tolkningsfaktor en hittil ubrukt mulighet. Det er en mulighet Høyesterett bør gripe. 